\title{
Paracedicus baram Levy, 2007 is a New Record for Turkish Spider Fauna
}

\author{
Adile Akpinar \\ Gazaintep University, Science and Art Faculty, Department of Biology \\ Gaziantep/Turkey \\ E-mail: aozdemir@gantep.edu.tr
}

\begin{abstract}
Paracedicus baram Levy, 2007 belonging to Cybaeidae family is recorded for the first time from Turkey. Characteristic features, copulatory organs and photographs of habitus are presented with information on distribution of the species.
\end{abstract}

Keywords: Paracedicus baram Levy, 2007, Cybaeidae, new record, Gaziantep.

DOI: $10.7176 /$ JSTR/5-9-09

\section{Introduction}

Cybaeidae Banks, 1892 family are ecribellat spiders and have eight eyes. Paracedicus Fet, 1993 have 2 pointed apophysis in males (Nentwig et. all, 2019). However, disagreement on this family and genus still continuous (Zamani and Marusik, 2017; Marusik and Guseinov, 2003). Currently, genus and species belong to the Cybaeidae family in the world spider lists (World spider catalog, 2019).

Paracedicus is a little known spider genus including 7 species on the world (World spider catalog, 2019) and no species Turkey (Danisman et al, 2019). With this study, it will be added Paracedicus genus and P.baram for the first time the Turkey spiders list.

\section{Material and Method}

The specimens were obtained by manuel collection and from under stones. The species were preserved in 96\% ethanol. Examined specimens are deposited in GAUNZM (Gaziantep University, Zoology Museum). The identification and image of pedipalp were made by means of a Toup Tek Toup View Digital camera attached to a SZX12 Olympus steromicroscope.

\section{Results}

Family: Cybaeidae Banks, 1892

Genus: Paracedicus Fet, 1993

Paracedicus baram Levy, 2007

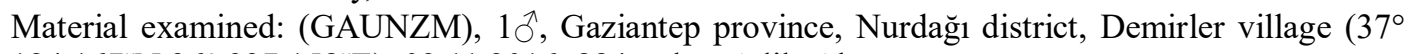
124 167"N $36^{\circ} 937$ 158"E), 03.11.2016, 884m, leg. Adile Akpınar.

Description: (Figure1). Carapace length 3,8 mm, opisthosoma length 4,6 mm. Prosoma light brown and ocular area is darker than the prosoma. Chelicera is dark brown or almost black, with one large and many small teeth (Figure 1b). Legs light brown and bristly, not annulated. Opisthosoma dark grey or blackish, dorsum with two light bands.

Palp: It has two apophysis, the first (tibial) is fork-shaped and equal length, the other (patella) is oval (figure 1e). Embolus long and hook-shaped (figure 1d) See Levy, 2007 for detailed description.

Distribution: Israel (Levy,2007) 

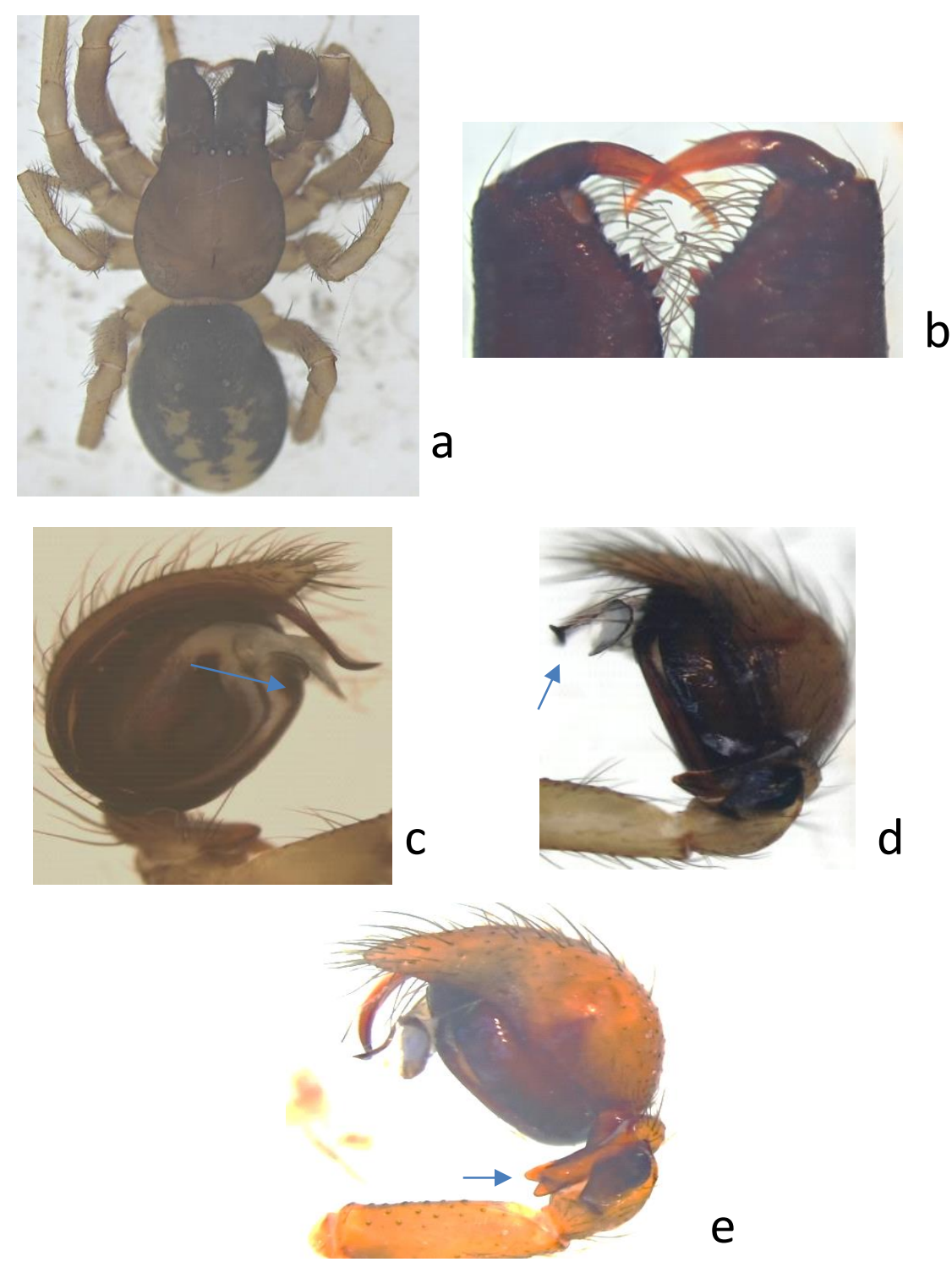

e

Figure 1. Paracedicus baram $\lesssim$ a) habitus, b) chelicera, c) palp ventral, d, e) palp retrolateral view.

\section{Discussion}

In this study, a little known species added to the list Turkey spider. The shape of P.baram male palpus different all other Paracedicus, Cedicoides and Cedicus species. Therefore, the species and genus are still discussed in categorization Desidae and Cybaeidae famililies.

\section{References}

Danışman, T., Kunt, K.B. and Özkütük, R.S. (2019). The Checklist of the Spiders of Turkey. Version 2018, Online at http://www.spidersofturkey.info

Levy G. (2007). Calommata (Atypidae) and new spider species (Araneae) from Israel. Zootaxa 1551: 1-30.

Marusik Y.M, Guseinov E.F. (2003). Spiders (Arachnida: Aranei) of Azerbaijan. 1. New family and genus records. Arthropoda Selecta.12(1): 29-46. 
World Spider Catalog. (2019). World Spider Catalog. Version 20.5. Natural History Museum Bern, online at http://wsc.nmbe.ch, accessed on \{August,2019\}. doi: 10.24436/2

Zamani A, Marusik Y.M. (2017). Six new species of spiders (Arachnida: Araneae) from Iran. Oriental Insects, http://dx.doi.org/10.1080/00305316.2017.1282386 